Multidisciplinary Journal - Volume 3, Nomor 2, 2020

Contents list available at Multidisciplinary Journal website

Multidisciplinary Journal

Journal homepage: https://jurnal.unej.ac.id/index.php/multijournal

\title{
Analisis Pelayanan Obstetri Neonatal Emergensi Dasar Berdasarkan Program $Q A$ di Puskesmas PONED X Kabupaten Bondowoso
}

\author{
Analysis Basic Emergency Obstetric and Neonatal On The QA Program \\ in PONED X Health Centre Bondowoso Regency \\ Asti Nuris ${ }^{1}$, Al-Munawir ${ }^{2}$, Dewi Rokhmah $^{3}$
$1_{\text {Mahasiswa Pascasarjana Ilmu Kesehatan Masyarakat Universitas Jember }{ }^{2} \text { Fakultas Kedokteran Univeristas Jember }{ }^{3} \text { Fakultas }}$ \\ Kesehatan Masyarakat Universitas Jember \\ Email: asti.nuris@gmail.com
}

\begin{abstract}
ABSTRAK. Memberikan pelayanan yang bermutu dan memuaskan kepada pasien merupakan suatu tuntutan yang harus dipenuhi oleh Puskesmas PONED sebagai salah satu program pemerintah untuk menurunkan angka kematian ibu dan bayi. $Q A$ merupakan bentuk program menjaga mutu suatu Puskesmas.Tujuan penelitian ini adalah untuk menganalisis pelayanan obstetri neonatal emergensi dasar menggunakan program $Q A$. Rancangan penelitian menggunakan pendekatan kualitatif dengan 4 informan yang terdiri informan kunci, utama, dan tambahan secara indept interview. Hasil penelitian menunjukkan bahwa $Q A$ dari variabel input belum memenuhi dan mendukung pelaksanaan PONED. Variabel proses pelayanan belum dilaksanakan sesuai protap. Variabel output capaian kinerja belum optimal
\end{abstract}

Kata Kunci: PONED, QA,Mutu

ABSTRACT. As health service provider, primary health care should provide qualified and satisfied service among patients. The PONED is government's program to reduce the maternal mortality rate. On the other hand, $Q A$ is a program used to preserve the quality of primary health care. The aim of this study is to analyze basic emergency neonatal obstetric by using $Q A$ program. This is qualitative study, where there were four informants in this study, consist of key-, main-, and additional- informant. Furthermore, the data was collected by in-depth interview. This study found that the variable of input of $Q A$ has not fulfilled and supported the implementation of PONED. The variable of process has not performed in accordance with the procedure yet. On the other hand, the variable of output showed that the performance has not been optimal yet.

Keyword: PONED, QA, Quality

\section{Pendahuluan}

Mutu Pelayanan obstetri neonatal emergensi dasar merupakan salah satu faktor yang dapat menunjang dan menentukan tercapainya derajat kesehatan masyarakat. ${ }^{1}$ Keberhasilan suatu pelayanan ditentukan oleh konsistensi kualitas pelayanan yang diberikan dan dilaksanakan oleh tenaga kesehatan yang kompeten.

Puskesmas PONED dituntut memberikan pelayanan yang bermutu sehingga diharapkan pasien akan puas dengan pelayanan yang diberikan baik dari segi sarana prasarana serta petugas ${ }^{2}$. Pelayanan bermutu yang diberikan dapat menurunkan diharapkan dapat menurunkan angka kematian ibu dan bayi.

Angka kematian Ibu di Jawa Timur tahun 2018 mencapai $91,45 \%{ }^{3}$, sedangkan di Kabupaten Bondowoso tahun 2018 terdapat 19 orang kematian ibu. ${ }^{4}$. Puskesmas PONED merupakan Puskesmas rawat inap yang mampu memberikan dan menyelenggarakan pelayanan obstetri dan neonatal emergensi tingkat dasar ${ }^{5}$.

Penanganan komplikasi dan kegawatdaruratan yang dapat ditangani di Puskesmas PONED meruapakan salah satu goal dari pelaksanaan pelayanan PONED yang ditentukan oeh input dimana sistem pelayanan tersebut berjalan dengan baik jika didukung oeh input yang memadai ${ }^{6}$.

$Q A$ dalam pelayanan kesehatan dapat dilihat dan dinilai dari segi input, proses, dan output. $Q A$ dari segi input merupakan suatu kebutuhan operasional yang dibutuhkan dalam mendukung pelayanan yang terdiri dari sarana dan prasarana, sumberdaya yang mendukung sesuai keahliannya. $Q A$ dari segi proses merupakan suatu pelaksanaan pelayanan yang diberikan disesuaikan dengan 
protap yang ada. Sedangkan $Q A$ dari segi output yaitu kelengkapan petugas dalam mengisi rekam medis serta kepuasan pasien yang dirasakan dari pelayanan yang telah diberikan oleh tenaga kesehatan.

Penelitian ini dilakukan di Puskesmas X karena pada dua tahun terakhir menyumbang AKI terbanyak sebanyak 4 orang di Kabupaten Bondowoso sehingga peneliti tertarik untuk melakukan penelitian terkait $Q A$ nya apakah sudah sesuai dengan standar. Penelitian ini dilakukan dengan tujuan menganalisis pelayanan obstetri dan neonatal emergensi dasar menggunakan pendekatan $Q A$.

\section{Metode Penelitian}

Penelitian ini merupakan penelitian kualitatif dengan pendekatan deskriptif. Pengumpulan data melalui indept interview atau wawancara mendalam dan observasi. Penelitian dilaksanakan pada bulan Juni 2019. Teknik penentuan informan menggunakan purposive sampling. Informan utama terdiri dari 1 orang yaitu koordinator PONED (Bidan), informan kunci 1 orang yaitu Kepala Puskesmas, dan informan tambahan 2 orang (Pasien).

\section{Hasil danPembahasan}

\section{A. Karakteristik Informan}

Informan utama berjumlah 1 orang, berjenis kelamin perempuan. pendidikan terakhir D4 Kebidanan.

Informan kunci berjumlah 1 berjenis kelamin laki-laki, pendidikan terakhir S2 Manajemen Kesehatan.

Informan tambahan 2 orang berjenis kelamin perempuan, pendidikan terakhir SMA.

\section{B. Analisis Hasil Wawancara Mendalam dan Observasi}

1. $Q A$ berdasarkan variabel input

a. Sarana dan Prasarana

Sarana dan prasarana yang ada di Puskesmas PONED $X$ belum sesuai standar pedoman pelaksanaan PONED dan belum lengkap. Berdasarkan hasil observasi bahwa ada beberapa standar ruangan yang belum ada yaitu ruang perawatan khusus kasus kebidanan, ruang tindakan khusus gawat darurat maternal dan neonatal, ruang pemulihan pasca persalinan.

Berdasarkan wawancara yang dilakukan bersama informan utama bahwasanya selama ini hanya ada ruang bersalin VK. Untuk tindakan gawatdarurat dilakukan di ruangan VK tersebut begitupun pada saat pemulihan setelah melahirkan tetap brada di ruang VK. Hal tersebut sesuai pernyataan informan dalam kutipan :

"Selama ini ya ruang VK bersalin jadi multifungsi mbak hehe, dari melahirkan sampai observasi postpartum ya tetep di VK itu mbak" (IU, 49 tahun)

Sehingga jika saat pasien banyak maka kekurangan ruangan dan hal itu menjadi kendala bagi Puskesmas dalam memberikan pelayanan dan hal itu menyebabkan pasien merasa tidak puas dengan kondisi sarana yang terbatas. Hal itu disampaikan oleh informan dalam kutipan :

"Kendalanya kalau pas pasien sudah banyak itu bingung ruangan jadi koordinasi dengan epala ruangan UGD jika memungkinkan untuk meminjam ruangan bahkan kadang ditolak dan disarankan untuk ke Puskesmas sebelah" (IU 1, 49 tahun)

\section{"Ruangannya terlalu sempit jadi pengap dan kurang nyaman aja sih mbak” (IT 1, 25 tahun)}

Begitupun juga untuk kasus-kasus kebidanan yang rawat inap selama ini jadi satu dengan pasien rawat inap keperawatan umum karena memang tidak ada ruang khusus untuk rawat inap kasus kebidanan. Jadi selama ini Puskesmas X memanfaatkan ruangan yang ada. Hal itu disampaikan oleh informan dalam kutipan :

"Kalau ruangannya belum lengkap dan memang belum sesuai standar tapi sejauh ini berusaha mengkondisikan dengan baik ruangan yang ada mbak" (IK, 51 tahun)

Sarana dan prasarana yang memadai menjadi salah satu faktor penting dalam mendukung pelayanan ${ }^{7}$. Sarana yang lengkap juga dapat memberikan kepuasan tersendiri bagi pasien maupun keluarga pasien yang berkunjung dan yang mendapatkan pelayanan.

Suatu Puskesmas bagaimana dapat memberikan pelayanan yang bermutu sedangkan sarana dan prasarana tidak mendukung dan tidak memadai. Peralatan dan juga obat-obatan di Puskesmas PONED X belum lengkap. Ada beberapa alat yang sudah rusak dan tidak layak pakai sehingga Puskesmas PONED harus melakukan perencanaan terhadap pengadaan barang, alat, dan obatobatan untuk menunjang pelayanan yang bermutu.

Peralatan dan obat-obatan juga menjadi faktor penting dalam memberikan pelayanan yang bermtu sehingga pasien mendapatkan pelayanan dan tindakan yang tepat sesuai protap ${ }^{8}$.

b. Sumber Daya Manusia

Puskesmas PONED dalam memberikan Pelayanan seharusnya didukung oleh sumber daya memadai, sesuai standar kualifikasi dan kompetensi ${ }^{6}$. Pendidikan minimal tenaga kesehatan yang terlibat dalam pelaksanaan PONED adalah D3 kesehatan untuk bidan dan perawat. Sedangkan untuk dokter minimal S15.

Tim inti di Puskesmas $\mathrm{X}$ terdiri dari Kepala Puskesmas sebagai penanggung jawab, 1 Dokter umum, 2 Bidan, dan 1 Perawat yang telah mendapatkan SK dari Kepala Dinas Kesehatan Kabupaten Bondowoso. sedangkan untuk tim pendukung terdiri dari 19 bidan yang mendapatkan SK Kepala Puskesmas yang juga dijadwalkan bergantian dengan 3 shift perhari.

Ketersediaan jumlah tenaga sudah cukup dan sesuai dengan kualifikasi bahwa bidan dan perawat minimal telah menempuh D3 kebidanan dan keperawatan dan untuk dokter umum yang masuk dalam tim PONED juga telah memenuhi standar kualifikasi yaitu S1 Kedokteran. Hal itu disampaikan informan dalam kutipan :

"Kalau pendidikannya sudah memenuhi 
kualifikasi semua mbak baik dokter, bidan, dan perawatnya. Semua juga sudah punya STR dan SIP lengkap" (IU, 49 tahun)

Berdasarkan hasil wawancara dengan informan bahwasanya ada beberapa kendala meskipun jumlah dan kualifikasi telah memenuhi standar yaitu untuk dokter yang masuk dalam tim PONED tidak berjaga 24 jam di Puskesmas tetapi hanya ada pada saat shift jaga pagi sehingga untuk kesiagaannya masih kurang dan tidak cepat jika sewaktu-waktu ada pasien gawat darurat yang membutuhkan penanganan dan atau konsultasi dokter hal tersebut disampaikan informan dalam kutipan :

"Kita ada 3 shift tapi dokter standby hanya shift pagi aja mbak, selebihnya via telfon sih. Dan selama ini yang berperan banyak ya bidannya mbak padahal 1 tim itu ada dokter dan perawat juga" (IU, 49 tahun)

Tenaga kesehatan yang memenuhi standar kualifikasi dan kompetensi ditunjukkan dengan adanya Surat Tanda Registrasi dan Surat Ijin Praktik sehingga punya legalitas yang tinggi dalam memberikan pelayanan ${ }^{10}$.

Pelayanan puskesmas yang bermutu juga didukung oleh tenaga kesehatan yang kompeten yang seharusnya siap 24 jam baik dokter, bidan, dan perawat. Selama ini yang banyak berperan dalam pelayanan PONED adalah Bidan sehingga Puskesmas PONED $X$ perlu mensosialisasikan kembali terkait uraian tugas dari masing-masing tnaga kesehatan yang trgabung dalam tim PONED.

\section{2. $Q A$ berdasarkan Variabel Proses}

$Q A$ berdasarkan proses merupakan suatu pelaksanaan dalam Pelayanan kegawatdaruratan obstetri dan neonatal dilaksanakan sesuai protap yang ada $^{9}$. Berdasarkan hasil observasi bahwa tindakan yang dilakukan oleh tenaga kesehatan ada beberapa yang belum sesuai dengan protap yang ada.

Pada saat penelitian dilakukan ada kasus ibu bersalin dengan HPP (Perdarahan) sehingga harus dilakukan infus kanan dan kiri untuk mengganti darah yang keluar banyak sehingga sibutuhkan abocath ukuran 18 namun ternyata abocath dengan ukran 18 kosong sehingga dari tidak tersedianya alat tersebut sudah tidak sesuai dengan protap yang seharusnya dan hal itu dapat merugikan pasien sehingga dikhawatirkan terjadi kematian ibu karena tidak tertolong dengan baik.

Perlu dilakukan perencanaan yang matang untuk obat-obatan dan peralatan sehingga kasus-kasus sepeti diatas tidak terulang dikemudian hari. Selain itu juga perlu dilakukan evaluasi terhadap ketrampilan petugas agar lebih patuh lagi dalam melakukan tindakan sesuai protap yang ada. Hal itu sesuai kutipan informan :

"Iya mbak kesalahan kita tidak memperhitungkan kebutuhan obat dan alat setiap tahunnya dengan benar makanya ya kayak gini ini dah kehabisan stok" (IU, 49 tahun)

Tindakan yang dilakukan sesuai protap akan mengurangi angka kesakitan dan kematian bagi ibu dan bayi dan memberikan rasa puas kepada pasien ${ }^{11}$. Hal itu disampaikan informan dalam kutipan :

"Ya penting kalau saya bayi lahir sehat dan selamat, petugas sabar ya puas saya dik. (IT 2, 30 tahun)

\section{3. $Q A$ berdasarkan Variabel Output}

$Q A$ berdasarkan variabel output yaitu dilihat dari kinerja PONED yang belum optimal. Berdasarkan hasil observasi bahwa untuk capaian kinerja masih rendah.

Cakupan pasien yang dirujuk dari wilayah kerja hanya mencapai $65 \%$, cakupan pasien yang dapat ditangani di Puskesmas PONED X mencapai 85\%, cakupan pasien yang dirujuk ke RS mencapai $70 \%$, cakupan persalinan yang ditolong oleh dukun pada tahun 2018 cukup tinggi yaitu dari 56 persalinan yang ditolong dukun sebanyak 10 persalinan. Hal ini menunjukkan bahwa kinerja PONED belum sepenuhnya optimal. Sehingga perlu diadakan evaluasi secara bertahap dan dilakukan pembinaan terhadap dukun dan meningkatkan kesadaran masyarakat.

\section{Kesimpulan}

Secara keseluruhan bahwa pelaksanaan $Q A$ dalam Puskesmas PONED X belum berjalan optimal dan masih ada beberapa kekurangan yang harus diperbaiki

1. $Q A$ Variabel input belum sepenuhnya memenuhi standar Pelaksanaan Pelayanan PONED

2. $Q A$ variabel proses belum sepenuhnya melakukan tindakan sesuai protap yang ada

3. $Q A$ variabel output capaian kinerja PONED belum optimal

\section{Ucapan TerimaKasih}

Terima kasih kepada seluruh informan yang telah bersedia menjadi responden dan terimakasih kepada Puskesmas PONED X yang telah berkenan memberikan ijin atas pelaksanaan penelitian ini.

\section{Referensi}

1. Departemen Kesehatan RI. 2012 Peraturan Presiden RI Nomor 72 tahun 2012 tentang Sistem Kesehatan Nasional. Jakarta : Depkes RI

2. Trihono. 2006. Arrimes Manajemen Kesehatan Puskesmas Berbasis Paradigma Sehat. Jakarta : Sagung Seto

3. Kementrian Kesehatan RI. 2018. Profil Kesehatan Indonesia. Jakarta : Badan Penerbit Kemenkes RI

4. Dinas Kesehatan Kabupaten Bondowoso. 2018. Profil Dinas Kesehatan Bondowoso. Bondowoso: Badan Penerbit Dinas Kesehatan Bondowoso

5. Kementrian Kesehatan RI. 2013. Pedoman Penyelenggaraan Puskesmas Mampu PONED. Jakarta : Badan Penerbit Kemenkes RI

6. Valentine, Suparwati, A., \& Suryoputro, A. 2016. Analisis Pelaksanaan Sistem Pelayanan Obstetri Neonatal Emergensi Dasar (PONED) di Puskesmas Sitanggal Kabupaten Brebes. Jurnal Kesehatan Masyarakat, 4 (4) : 154-161

7. Walyani. 2015. Asuhan Kebidanan Kegawatdaruratan Maternal Neonatal. Yogyakarta : Pustaka Baru Press

8. Rachmawati, T \& Suprapto, A. 2010. Inovasi Implementasi Puskesmas PONED dalam Upaya Akselerasi Penurunan Angka Kematian Ibu dan Bayi di 3 (Tiga) Kabupaten di Jawa Timur. Buletin Penelitian Sistem Kesehatan, 13 (02) : 8-15

9. Sukma, S., Sudiro, S., \& Fatmasari, E et al. 2017. Analisis perencanaan Quality Assurance ditinjau dari aspek input pelayanan keperawatan rawat inap pasca areditasi paripurna RS Swasta X Kota Semarang. Jurnal Kesehatan Masyarakat, 5 (4) : 1-10 
10. Peraturan Menteri Kesehatan Nomor 75 tahun 2014. Pusat Kesehatan Masyarakat. Jakarta : Kemenkes RI

11. Al Jebore,H., Khaleel,M., \& Hussein,K. 2018. Quality assurance of Essential Primary Health Care Servce at Primary Health Care Centers in Al-Najaf Al-Ashraf Govemorate. Journal of Global Pharma

10

(03):900-90 